\title{
Żaneta Nalewajk
}

\section{Translated by David Malcolm}

\section{Literature - Literary Studies - Philosophy: Problems of Relation, Languages, and Communication}

The cluster of problems of the relations among literature, philosophy, and literary studies does not belong among issues that have been resolved, methodologically defined, or exhaustively described. It is difficult to speak in this respect of the existence of some "grammar", of a model that would indicate all possible connections between them. We encounter even more difficulties when we acknowledge that both the mentioned disciplines employ different but homogeneous languages that possess precisely defined rules for creating correct utterances. However, it must be conceded that the repertoire of these principles is finished, but simultaneously is such whereby it is possible to complete an infinite number of operations within the lexicons of individual areas. With irresistible force, the issues arise of the aims and possibilities of "translating" each of these languages into the "foreign" language of the other discipline, and also the principles of such a "translation". No less vital are the questions of what conditions have to be fulfilled so that the specific nature of these discourses is saved in "translation", and so that there could emerge a functional theory of such "translation".

Inspired by Janusz Sławiński's sketch "Wypowiedź literacka a wypowiedź filozoficzna: trzy kwestie i jedna ponadto" ("The Literary Utterance and the Philosophical Utterance: Three Issues and One More"), I would like to look at this cluster of issues from a literary-studies perspective. Sławiński, weighing up the relations among the issues in the title, outlines three typical situations in which the literary scholar feels the temptation to embed the subject of his studies among problems that usually absorb philosophers.

We face the first of them when the interpreter deals with works that Sławiński describes as "prequalified in terms of subject area", that is works that placed themselves originally in the field of philosophical discourse, and only subsequently, with the passage of time, did their reception become closer and closer to the reception of belles lettres. It is significant that the above-mentioned conversion does not always have to have a diachronic character, but can be observed also in synchrony. If we assume the separation of the disciplines (of philosophy and literary studies), this case projects at least two types of reading of a literary text: its transference in interpretative practice to a philosophical tradition, or making the departure point for study one from, for example, historical poetics. 
There are, however, such hybrid genres - as Sławiński points out - such as the essay, which by definition are situated at the intersection of discourses, but which simultaneously do not observe, in any normative fashion, the rules of any of them. They place a question mark against genre identity, and cast doubt on the laboriously developed classifications of literary forms. Discussion of texts, within which we are dealing with genre polymorphism, leads us frequently to question the point of creating a systematic outline of those genres. It provokes one to ask questions like: "Is a poetics of the essay possible?" (Markowski 109-119). And the question is not a trivial one, because the specific nature of the answer given to it simultaneously sets the borders beyond which the literary scholar will be unable to go in his discourse, if the scholar using that discourse is interested in any of the following: a concern about the "purity" of the discipline, an effort to protect the specificity of its language, and a need to counteract the tendency to subordinate the discourse of literary studies to that of philosophy.

The example of the essay - frequently a multi-themed work - from the point of view of its digressiveness and its genre "refractoriness" (which is often apparent in its unwillingness to observe the rule that says that a coherent text is one which is an utterance on one topic, an utterance rigorously kept within one style and devoted to a set of problems that is at the enter of only one discipline of knowledge), allows us to raise the problem of the borders of research and discussion in literary scholarship. It is not a question of there having been no effective attempts to define the poetics of the essay. On the contrary'.

1 See, for example: Kowalczyk, "W kręgu poetyki eseju". Kryzys świadomości europejskiej w estetyce polskiej lat 1945-1947. Vinenz. Stempowski, Miłosz, 7-43. A different position in the matter of attempting to create a poetics of the essay is represented by M.P. Markowski, in whose opinion such a poetics is useless from a genre perspective, since the essay as a genre is marked by a low degree of normativity; further, from a rhetorical perspective it is unnecessary, since such a poetics offends against rule of the first of the three components of Okham's Razor"Do not multiply entities; do not create fictions; explain facts in the simplest way" - and repeats in a slightly different language conclusions inherited from the tradition of rhetorical thought. In Markowski's opinion, the creation of a poetics of the essay, if one considers the problem from a transhistorical perspective, appears unjustified, since "there is no way to construct a poetics of the essay on the basis of its functional otherness". In his opinion, too, the sense of looking for what is typical in literary utterances which cannot be located within the scope of "one, coherent vision of literary history and of discourses surrounding literature" (and, according to Markowski, there is no such vision) can only be seen as dubious. Such utterances consist, claims Markowski, in a "discontinuous series of displacements in a discursive polygon, the surfaces of which are rhetoric, philosophy, journalism, criticism, and self-presentation" (115-1 16). Markowski's observation points to a low level of conventionalization of the essay and exposes the difficulties that literary scholars may encounter in their attempts to create a poetics of the genre, and to trace its historical changes, for these have never been of a revolutionary nature. However, Markowski's insistence that there does not exist "one, coherent vision of literary history and of discourses surrounding literature", an insistence that is connected with the conclusion that excludes from the range of justified actions any attempts to describe the essay from the perspective of genre, is actually open to contestation. If we accept the thesis that there does not exist any holistic picture of literary change and changes in texts surrounding literature or of the constructive activities of literary scholars who only create "local narratives" instead of any total vision of history, it does not necessarily follow that reflections aiming at developing a poetics of the essay must be unjustified. Even if we are to accept the status of the poetics of a genre as a construct, even so it is impossible to exaggerate the importance of its role in ordering literary material, its contribution to accumulating knowledge in a systematized way. It is a part not only of literary tradition, but also of cultural tradition. It is true that systems constructed on what is typical cannot grasp the individual features of particular texts. However, this does not alter the fact that the ordering of the literary heritage makes it easier to pass on to future generations, offers a better chance that they will remember it, and is one of the factors that assists an attempt to maintain cultural continuity. 
The problem is a different one. It is this: if the literary scholar confines him/herself to a description of the text's form - an example here is Bolesław Miciński's essay "Portret Kanta" ("A Portrait of Kant") - and does not attempt to examine its intertextual references to the discourses of other disciplines (in this case, philosophy and art history), the commentator will only succeed in capturing the principle upon which this work, composed of heterogeneous elements, is built. But the anthropological content and the issues that are of interest in the history of philosophical thought vanish without trace, and it is, in fact, they that make up the final effect that this masterpiece of the essayist's art produces in the reader.

In "A Portrait of Kant", there coexist reflections from art history, the history of literature, and the history of ideas; biblical quotations exist alongside quotations from King Lear and from Kant's works; there is the poetry of Iwaszkiewicz and an interpretation of the frescoes of Michael Angelo. Biographical facts from Kant's life mingle with literary hermeneutics; however, the pervasiveness of certain motifs does not only serve to maintain particular aspects of the set of problems addressed by the essay in the reader's memory (problems that might become obscured in the course of reading) ${ }^{2}$, but also affects the emotions, and will not allow the reader to stop at an intellectual analysis of the text. In other words, "A Portrait of Kant" is one of the many examples that incline one to raising the problem of the distinctiveness of disciplines such as literary studies and the history of philosophy, the conditions of the possibility of communication among them, and also the sense of seeking out their mutual relations. At this point, one can ask a rhetorical question: without knowing the works of Kant, even if only those such as "Critique of the Power of Judgment" and "Prolegomena to Any Future Metaphysics" and references to them, is it possible to interpret Miciński's text, or even to define the topic of his essay? The problem can, however, be reversed and expressed as follows: without an elementary acquaintance with literary tradition and the poetics of genre, without recognizing that a literary text is an utterance governed by other laws than a philosophical one (expectations of the latter include: transparent and systematic argumentation, the hierarchical organization of its various sections, a respect for the principle of lack of logical contradiction, and construction in accordance with relations of inference), can Miciński's essay be seen as the work of an author who possesses sufficient intellectual discipline so that the course of its reasoning can be followed, the text's main assumptions can be reconstructed, and the mechanisms of coherence present within it can be identified?

Essays are not the only examples of texts that can be included among groups of works in which thematic and constructional polymorphism mean that the reading

\footnotetext{
2 That this is a conscious move on Markowski's part is shown in his commentary Od autora (From the Author), ontained in the essay under discussion (123).
} 
of such works should take place on several hermeneutic levels simultaneously. We have to deal with the possibility (the necessity?) of a parallel reading within the discourses of literary studies and philosophy at least when a literary work's title contains names that are typical for philosophical texts. I am thinking here of the presence of archetextual indications that use, for example, the terms "tractate," " philosophical tale," or "philosophical poem," which encourage the reader to look for a language that allows him/her to combine literary analysis with a philosophical perspective in interpretation.

In a similar fashion we can formulate the problem of the "discipline reformulation" of philosophical texts, of which Stawiński wrote. It is worth considering this matter from a slightly different perspective than that which Sławiński suggests in his "Wypowiedź literacka a wypowiedź filozoficzna: trzy kwestie i jedna ponadto" ("The Literary Utterance and the Philosophical Utterance: Three Issues and One More"). Is it the case that the "philosophical" poetics that undergoes conversion and becomes the object of analysis in literary studies is always, in fact, as Slawiński argues, "a poetics that is too weak to ensure them [texts originally philosophical - note ŻN] permanent genre identity"? (82). Is the difficulty in identifying what genre these texts belong to, which overlaps with the interest in them on the part of representatives of varying disciplines, who, after reading, decide to make them an object of study, really a testimony of "weakness"? One must agree with Sławiński that a problem with the genre allocation of a work need not always be testimony to its high cultural value, its necessary and at the same time sufficient condition, but there is also no way to assert unambiguously that the feature mentioned above should always be treated as a result of the philosopher's incompetence. Consequently, it is worth considering if philosophy and literariness always have to constitute the elements of a binary opposition. My view is that, with regard to the main aims and tasks of literary history (which include, among others: developing a periodization of the literary-historical process, following the evolution of motifs, ideas, and problems present in literary works that emerge in particular periods, and study of the changes in the reader's attitudes on a historical level), a recognition of the separateness of the disciplines, literary studies and philosophy, makes it easier to order phenomena, and it is worth seeing this as a rule. But this principle should not be maintained in an absolute and unqualified manner. A restrictive acceptance of the assumption that there exists no correspondence between the concerns of literary studies and philosophy, and that the areas of interest of these disciplines do not interact and are mutually exclusive without exception, this would lead to a reduction of the meanings of particular texts that are available for interpretation. In other words, sometimes the ambiguity of the genre or mode identification of a text is a source of the work's wealth of meanings and favors the accumulation of the information contained in the work. 
In this case, the search for communication between branches of knowledge, such as literary studies and philosophy, is justified. The effectiveness and legitimacy of this practice have, however, a limited scope and depend on the presence in the work of signals that do not permit the location of interpretation on only one hermeneutic level.

The second situation, described by Sławiński, in which a literary scholar feels the temptation to perceive the philosophical quality of a literary work is connected with the attempt by the scholar of language and literature to solve questions like the problems of "nature, history, time, moral obligation, the cosmos, the human being, etc" (82). Stawiński believes that the challenge, though it is frequently taken up, is not always taken up for reputable reasons. For the purpose of arguing his case, Sławiński enumerates the actions that, for understandable reasons, do not deserve the name of scholarly undertakings. Among these we find: intellectual sleight of hand, or taking words out of context. Sławiński euphemistically calls such a practice "appropriation from a text of suitable quotations, containing thoughts that by virtue of their importance or sublimity deserve to be called 'philosophical'" (82). Another somewhat more sublimated practice betrays, as Sławiński points out, a consciousness that there exist in the literary text various voices. As a consequence, what is philosophical in a work cannot always be identified with "the work's general pronouncement", its primary message. Quite the reverse, frequently it is possible to go to one of the points of view inscribed in the text, and to ascribe to this perspective substantial meaning, to extend that perspective and to project through it meanings onto the work as a whole. Sławiński is convinced that, on the surface at least, it is a sign of greater refinement to discover philosophical content in the deep semantic structure of a work, irrespective of whether it was explicite expressed or not. In this case, it not infrequently is a matter of a confusion of the object of research with the subject. In effect, the subject projects his/her own reflections on the text, places his discourse above the language of the text (which is then of course not analyzed), and he/she does not even pretend that things are any different.

This kind of practice certainly cannot serve as a model for an approach that meets the minimal conditions (necessary and sufficient) that must be fulfilled so that philosophical-literary reflections can aspire to be scholarly. It is, however, worth considering other cases too, which Sławiński does not discuss, such as when a writer directly speaks of his interest in the history of philosophic thought, in discursive texts attests to inspiration from individual positions, even if those inspirations have primarily a negative character (as in the case of Gombrowicz), finally creates within his/her own philosophy of culture (in theoretical works) the illustration of which are, indeed, his own literary texts (Witkacy is an example here), advances philosophical thought, urges people to shape 
and form themselves in this field, and gives lectures provoking the listeners with statements like "Just try for once, sweetie, to have a Weltanschauung" $\mathbf{3}$. In situations like these, can a reluctance to try to recognize and describe the philosophical quality of literary texts be justified by a concern for the purity of the discipline that the literary scholar follows. As one can see in my earlier remarks, in this matter I have serious fundamental doubts.

Sławiński points to one more strategy followed by literary historians, one that leads to an attempt to reconstruct the philosophical sources of a specific literary trend, of particular poetics, and literary programs. Unfortunately, an attempt to recreate the philosophical basis is often not accompanied by any systematic reflection, and does not involve an effort to place the scholar's reflections within one of the fields of philosophy, for example epistemology, ontology, axiology, or the philosophy of language. As a consequence, the scope of research is not defined, or precisely limited, and its object is not clearly placed within the framework of a concrete philosophical field. As a result, there is a mixing up of sets of problems: historiography is mixed with influences of "the study of all that is"; cognitive theory and the study of value also stop being separate. Further, philosophical concepts are treated as prior in relation to literary text-making praxis. They are understood as a condition for the possibility of that praxis's occurrence. The result is that not only writing literature, but also literary-historical research, lose their autonomy, begin to appear derivative and contingent, dependent on philosophical discriminations, and utterly subordinated to them. Their autonomy is placed in doubt.

\footnotetext{
3 Among others, Edward Balcerzan recalls Witkacy's reading in his text "Poezja filozoficzna. Bolesław Leśmian (i niewielu innych)". In this text Balcerzan tries to answer the question as to how philosophy can exist in poetry. He also presents a typology of philosophical poetry, distinguishing three main variants. The first of them is, written in poetic prose or verse, a poetic philosophical treatise, one of the types of poesis docta (learned poetry). The author of such should combine an acquaintance with the history of philosophy with the competencies of a philosopher and a poet. What is significant is that the literary means employed by the author in a text are subordinated to an attempt to express an original philosophical proposition, and their function lies in assisting the course of an argument. As Balcerzan notes, the tradition of poetic philosophical treatises goes back to antiquity, for example Lucretius's On the Nature of Things. But more modern times have retained an interest in this genre. It was brought up to ate not only by the Romantics (Słowacki's Genezis z Ducha), but also by the Positivists (Nad głębiami- a sonnet cycle by Adam Asnyk modelling the course of argument typical for a philosophical treatise). The poetic philosophical treatise also appears in the interwar period (O książce, Do księdza Ch. by Czesław Miłosz), and after the Second World War, for example Miłosz's Traktat moralny. The second variant of philosophical poetry mentioned by Balcerzan is a poetic illustration of a philosophical idea. The authors of such poetic texts draw inspiration from the tradition of philosophical thought in the following way: ideas that a given philosopher has set out in a language that is in most cases discursive are imaged forth by the poet by literary means. This poet does not create his/her own system, but draws on others' achievements replacing the language of the treatise with the language of poetry. Balcerzan cites as examples of this practice Jan Kochanowski's Treny, which illustrate the idea of stoicism, and the poem of Leopold Staff entiled Kowal, demonstrating the main assumptions of Nietzschean philosophy. Finally, the third variant of the philosophical literary texts is philosophy hidden in poetry, when the author combines the competencies of a poet and a philosopher, but expresses his own, original philosophical concepts using another language than that of philosophers. The problems located at the center of interest for philosophy are here dealt with by literary means. As Balcerzan writes: "Philosophy hidden in poetry requires decoding; it does not repeat ready answers, it repeats universal questions" (50). In Balcerzan's opinion, an example of this variant is the poem Nad wodq wielka i czysta by Adam Mickiewicz (in the collection Lyriki lozańskie), and, above all, the poetry of Bolesław Leśmian.
} 
As Sławiński rightly observes, the approach described above is one that still frequently occurs in the practice of research, but at the same time, and this is significant, it belongs among the least thought out and least problematized practices, both methodologically and in terms of content. In Stawiński's opinion, for this type of activity to achieve any kind of legitimacy, such practices require "support from an appropriate analytic technique that would make it possible to describe the transition from a text that constitutes a philosophical basis to a text that contains a normative theory of the writer's actions" (85).

Despite Sławiński's skepticism in this matter, the suggestion he formulates for developing adequate, verifiable research procedures that will permit a description of the relation between a general ("more elementary") philosophical concept, and the rules whereby literary texts are created, seems worth considering ${ }^{4}$. My view is that in relation to this kind of postulate, the rudimentary duty of a scholar who assumes the existence of such relations and who is willing to take up the challenge of proving them would be, thus, to define their character, to indicate whether in a concrete incidence we are dealing with the one-sided impact of a defined philosophical position on particular poetics or currents, or with a parallel appearance in a period of similar motifs and sets of problems both in philosophical texts and in literary ones, or whether we are looking at mutual influence (literature, after all, has frequently become the subject of considerations by philosophers such as Friedrich Nietzsche, Albert Camus, Hans Georg Gadamer, Martin Heidegger, and Lev Shestov, and a smaller number of writers and poets have explicitly indicated the philosophical sources of their artistic inspiration). In such a situation, the fear that to notice such cases must result in the subordination of literary studies in relation to philosophical reflection, will be excessive as long as philosophy does not work out a theory that can describe the way of existence of a literary work, cannot offer an account of the rules of its organization, does not propose authoritative observations on the subject of literary genres and modes, does not produce a breakthrough in thinking about the language and style of a literary text, and finally does not propose its own concept of the analysis of verse. Even if a history of the literary work is produced by a philosopher (history knows one example of this - Aristotle's Poetics), it's worth suggesting that a book like that will be more readily recognized as an attempt to create a descriptive and/or normative poetics, as an attempt to construct a theory of reception and of the internal structure of the literary work, than what is only and exclusively a philosophical utterance sensu stricto. Thus the problem of the above-mentioned subordination does not apply at all.

\footnotetext{
4 Sławiński claims that "The thesis declaring that the assumptions and rules of literary activity are derived from some more elementary utterance of a philosophical nature, remains a purely rhetorical declaration as long as it is not carried over into research that would offer a detailed view of the semantic process of that derivation. Hitherto it has not been so extended; one can doubt whether it will ever be so" (85).
} 
Reference in literary texts to the legacy of philosophical thought does not seem completely unreasonable not only when the scholar is possessed of the competence both of a historian and a theoretician of literature, as well as that of a historian of philosophy, and the object of analysis is hybrid in character, and combines in itself both the features of a literary utterance, as well as those of discursive texts referring directly to disciplines other than literary studies. As a further incentive for the literary scholar to look for the coincidence of discourses of varying branches of knowledge in literary texts one can consider the situation when a writer uses the terminology reserved fro philosophical discourse, and does that both in literary works and in diary texts or epistolographic ones, which allows one to treat them as utterances revealing the secrets of the conception of poetic, prose, or dramatic works. One could also imagine a research project, in which the interpreter aims to demonstrate a kind of "partnership" of the author of the work and the creator of a philosophical concept. Because in both cases the object of analysis are texts written in a distinct poetics, this a challenge connected with the analysis of them simultaneously from two perspectives, that of a literary historian and of a historian of philosophy (while maintaining the scholarly procedures particular to each of these disciplines), does not have to be condemned to failure from the start. After all, there are literary works that problematize the unstated premisses of philosophical positions and world views, or that show selected aspects of the world in a new light, just as there exist philosophical disquisitions dedicated to literature that are creative interpretations of it.

The matter becomes more complicated when the object of the literray scholar's reflections become the relationships between utterances of a philosophical nature written by a variety of thinkers, and the poetics of a select literary grouping or artistic current. This kind of research activity demands the adoption of the assumption that in this case we are dealing with two "collective subjects", of which one affects the other, or also both have a mutual effect on each other. Meanwhile the object of research may only become the individual concepts and the poetics of concrete artists. These difficulties mean that, sooner or later, it is necessary to ask fundamental questions. In the second half of the 1970s, Sławiński formulated the issue thus:

"Do situations appear in the work of a researcher into philosophical texts in which a suitably fashioned concept of the literary utterance would seem helpful? Does he/she in general need to take into consideration the dimension of "literariness" in order to increase his/her knowledge of the "philosophical quality" of texts?" (85-86)

To the issues indicated by Sławiński, one must add the following: does drawing on the legacy of philosophical thought help in understanding the mechanisms of the literary work? One of the possible answers to questions of this kind has been 
to agree (as mentioned above) to the assertion that the languages of philosophy and literary studies are unique, always autonomous, and untranslatable, one to the other. One can also recognize that literature and philosophy have their own grammars, and that the system of literary language is fundamentally different from the system of philosophical language. Research into one and the other should, thus, be conducted separately and should aim at the sytematization of the multiplicity of phenomena within the scope of each of the disciplines. Such an answer, however, does not eliminate the issues pointed out above, but simply removes them from the field of vision. In this way, vast areas of meanings specific to certain texts disappear from the horizon of reflection, texts in which the genre identity is difficult to define, because they are composed of heterogeneous elements, and also their belonging to a concrete field cannot be established unambiguous.

In "Wypowiedź literacka a wypowiedź filozoficzna: trzy kwestie i jedna ponadto", Stawiński expresses the suspicion that in the future this issue will become important both for literary scholars and for the historians of philosophy. After the passage of almost thirty years since the publication of his text it appears that his prognosis has, unfortunately, not turned out to be valid. Unfortunately, because when we look at publications in Polish on the subject of the relations among literature, philosophy, and literary studies, we are struck by a lack of texts that reveal any ambition to develop a comprehensive understanding of the problem. As a rule, in any reflection on the possible links between philosophy and literature, consideration is given to the differences and similarities among particular philosophical positions ${ }^{\mathbf{5}}$, and the general message of literary works (references to the former are usually a point of departure for the hermeneutics of individual texts) or the object of analysis becomes an understanding of literature inscribed in particular philosophical conceptions ${ }^{6}$. Or consideration is given to the philosophical contexts of literature ${ }^{7}$. However it is significantly rarer for scholars to take as the object of analysis their own procedures that permit a juxtaposition in one study of the discourses of two separate disciplines. Infrequently do they ask about the conditions of possibility and the validity of the strategies

\footnotetext{
5 The following texts can be seen as examples of such insights: K. Okopień, "Dwie fenomenologie: Husserl i Gombrowicz". Wypowiedź literacka a wypowiedź filozoficzna. Z dziejów form artystycznych w literaturze polskiej, Eds. Michał Głowinski \& Janusz Sławiński. 121-130; M. Wyka, "Próba parareli: Gustaw Herling-Grudziński i Albert Camus". Niecierpliwość kryłyki. Studia i szkice z lat 1961-2005.

6 See, for example: K. Bartoszyński, "Teoria miejsc niedoookreślonych na tle Ingardenowskiego systemu filozoficznego". Wypowiedź literacka a wypowiedź filozoficzna..., 183-197; D. Ulicka, Ingardenowska filozofia literatury; K. Rosner, "Ingardenowska koncepcja budowy dzieła literackiego jako źródło inspiracji do analizy komunikacji artystycznej".; M. Januszkiewicz, Tropami egzystencjalizmu w literaturze polskiej XX wieku: o prozie Aleksandra Wata, Stanisława Dygata i Edwarda Stachury.

7 See: J. Kurowicki, Normalność jako sen idioty (wykłady o kulturowych i filozoficznych kontekstach literatury współczesnej).
} 
adopted. It is not a matter of assuming the lack of such validity. After all, there exist texts that sow confusion in the universe of precise demarcations and classifications of forms of utterance. As Stawinski writes:

"... they steadfastly oppose all attempts to accommodate them to some typology of utterances. Both poetry and philosophy seem incessantly to wander in the field of stable forms of speech. There is no way to characterize them by indicating the place they take up, for they are hopelessly without such a place. No particular location of any kind is characteristic for them, but rather, indeed, an avoidance of localizations - a shiffing among codified discourses, institutionalized in social praxis, tracks of movement, and unexpected neighbors. They do not recall functional languages (as linguistics conceives of them), fulfilling certain fixed parameters of communicative usefulness, and thus do not echo, for example, scientific disciplines, law, or the language of the bureaucracy... They cut across the territories of ordered and delimited discourses, challenging ambient boundaries and divisions of competence" (86-87).

Research into such works, if we assume an unconditional separation of particular areas of knowledge, lead to monoaspectual reflections; however, in a situation when the interpreter wishes to deal with a text on several levels, he/she is faced with the necessity of going beyond the discourse of one discipline, or at least of realizing what kind of procedures make such a transgression possible. In this last case, the presence in one work of a set of problems that is at the centre of interest of two separate disciplines forces the scholar to search for a language that places itself at their intersection, or that would allow a recognition and description of liminal issues. He/she is open thus to reproaches that the insights formulated in such a study do not deserve to be called either "pure literary studies" or "pure history of philosophy", and may be described as "eclectic".

\footnotetext{
8 In a brilliant and perverse text, written with a sense of humor, Janusz Sławiński's Wzmianka o eklektyzmie reconstructs the charges that may be laid against the scholar-researcher whose actions are identified as the practice of eclecticism. Among these Sławiński counts uneven style (lack of elegance), inappropriateness, incorrectness (departure in research from faithfulness to methodological universals), and not having anything new to say. Stawiński also constructs three models of attitudes that match positions from which eclecticism can be criticized. From the point of the view of the aesthete, the lack of homogeneity of the issues considered in the text, and the references in it to diverse systems of concepts, must lead to a breach of the principle of decorum. Lack of concern in an eclectic study for the demand for uniformity of style, when seen from this perspective, cannot be justified even by a high level of facility or functionality on the part of utterances the authors of which avail themselves of more than one methodological school. On the other hand, in the view of the doctrinaire, that is a scholar who sees him/herself as a representative of the only correct theory, eclecticism is unacceptable since, as opposed to the best methodology, it cannot lead to indisputable knowledge. The confusion that eclecticism brings serves no one and brings no profit to the doctrine. The doctrine itself, treated as the language of privileged elucidations, recognized as the best of all possible conceptions, does not, after all, require any innovations, supplements, or qualifications - much less a problematization conducted from border positions. Equally, for the purist, eclectic moves are hard to accept. They can be seen as acquiescing in a normative model of correctness common to all forms of scholarship and science. In a discussion with the purist, the eclectic is not helped by an argument through example, pointing to the heterogeneity and specificity of the subject of research, which does not permit the application of a model analytic procedure. For the purist, indeed, uncontroversial correctness in getting to results is more important than aiming at experimentation in the field of applying and adapting procedures to analyze and interpret new empirical material, which might lead to a growth of knowledge. There is no question that verification of eclectic conceptions is significantly more difficult than that of works faithful to one research approach, in the event of which value is placed on, inter alia, congruence with the realization of the principles of a concrete theory or of a conceptual system (36-41).
} 
The abovementioned situation, because of the lack of identity and homogeneity of the paradigms within which the text may be situated, poses a number of methodological problems. The following questions arise: Is it permissible - and if so, on what principles - to combine different research approaches, ones that are situated not just within the scope of one discipline, but that belong, for example, to two areas of knowledge recognized as heterogeneous? Can one describe it as valid in one study to draw simultaneously on the repertoire of forms of philosophical language and also the treasury of literary-studies discourses? Is it necessary here to speak in every situation of an unauthorized mixture, violently breaking the rules of elementary methodological correctness, of utterances of differing origin and status, or is it also permissible (and if so, in what case) to treat their joint appearance in one study as an arfful translation of the language of one defined discipline into that of another? Finally, how mutually translatable is the terminology of these disciplines? Is there any chance of communication between differing areas of knowledge?

It may be partly possible to defend oneself against the charge of eclecticism by precisely fixing a corpus of texts, in the analysis of which a heterogeneous language might be applied, and, thus, defining the scope of the acceptability of the use in scholarly research of dissimilar discourses and in the description of the purpose of looking for correspondences between them. In the case of hybrid works, the conviction that the discourse of one discipline will always be more authoritative than the language of the other, is far from obvious, and it is difficult to consider it other than controversial, exclusively obligatory, impossible to problematize and to challenge. In my opinion, the measure of the value and purpose of applying this approach are the results achieved in the course of research, the accuracy and efficiency employed in applying analytic procedures, consistency in implementing the assumptions accepted, and whether it is able to generate a development in knowledge. To fulfill these requirements is perhaps to realize one of the postulates formulated by Sławiński, that is the postulate of "constructing... a theory of eclecticism as a scholarly activity" (Sławiński, Wzmianka o eklektyzmie 43).

As Sławiński notes:

"It is by no means excluded that in the course of the discussion accompanying this work, it could become apparent that an eclecticism that is conscious of itself may constitute at present the one basis for those trends that appear under the exalted slogans of "interdisciplinarity" and "integration" of knowledge" (44).

When analyzing Sławiński's suggestion it is worthwhile, I think, to ask a question: Is the practice of an eclecticism formulated as an ordered and replicable means of engaging in research that will lead to defined results, actually still eclecticism, or is it simply a new methodology, the application of which is justified when the object of theoretical 
representation is heterogeneous? The abovementioned heterogeneity frequently produces a need to describe the subject of research in a non-homogeneous discourse. I think that this should be the case when it makes possible a broadening of research horizons, and the ascertaining in the work of contents that would go unseen without the confrontation of dissimilar languages.

On deciding to adopt such a research strategy for a text, the literary scholar should reckon with the fact that he/she will encounter the problem of legitimizing the language/languages of description that he/she employs. It is another matter that, at present, all discourses struggle with the dilemma of legitimatization, but such a situation inclines one to wonder if theory, as a result of the critique of the mimesis of a work in theoretical construction, has crossed over into a "postrealist" phase. It seems to me that this is not necessarily so. The more aspects of a work that it is possible for a concrete theory to seize upon from many different perspectives and by means of defined or clearly set out research methods, the less is the likelihood that it will encounter the reproach that it is postrealist. In concrete examples - I wrote of this earlier - such a theory will also have to wrestle with the multilingual and genre polymorphic nature of literary texts, which form the objects of the observations that it formulates.

Since - as Sławiński has observed - both the poet and the philosopher see a problem in the lack of steady allegiance of their own utterances to one discourse, it seems that at the base of their activities there resides a notion of a certain utopian possibility of communication. Stawiński, however, emphasizes:

"It is not a utopia without telling realizations - and therefore the situation of the literary and philosophical utterance cannot fail to be a troublesome challenge to the theory of discourses" (Sławiński, Wypowiedź literacka a wypowiedź filozoficzna 87).

This utopia results from the feeling that it is possible to formulate substantial observations in a language that goes against the rules of institutionalized codes of speech. The scholar will find himself in an analogical situation (connected with the necessity of developing a new language) if he/she wishes to describe their borderline status not just in negative categories (for example, by specifying the rules of discourse that have been violated in a particular texts).

This "troublesome challenge", which the theory of discourses must face up to, is identical, it turns out, to the problems of communication between individual branches of knowledge, problems that, hitherto insufficiently recognized, still wait for some revelatory discussion. It is not impossible that the realization of this task will demand the adoption of the maximum assumption that there exists a level of universal text grammar embracing all reflection around anthropological topics. The search 
for this grammar should, however, take place with full respect to available knowledge on the subject of the status of texts, their genres, and the specifics of the languages of the disciplines to which these languages belong.

\section{Works Cited:}

Balcerzan, Edward. "Poezja filozoficzna. Bolesław Leśmian (i niewielu innych)". Przestrzenie świadomości. Studia z filozofii literatury. Poznańskie studia z filozofii humanistyki 3 (1996). Print.

Bartoszyński, Kazimierz. "Teoria miejsc niedookreślonych na tle Ingardenowskiego systemu filozoficznego". Wypowiedź literacka a wypowiedź filozoficzna. Z dziejów form artystycznych w literaturze polskiej. Eds. Michał Głowinski \& Janusz Sławiński. Wrocław: Wydawnictwo Polskiej Akademii Nauk, 1982. Print.

Januszkiewicz, Michał. Tropami egzystencjalizmu w literaturze polskiej XX wieku: o prozie Aleksandra Wata, Stanisława Dygata i Edwarda Stachury. Poznań: Redakcja Serii "Poznańskie Studia Polonistyczne", 1998. Print.

Kowalczyk, Andrzej Stanisław. "W kręgu poetyki eseju". Kryzys świadomości europejskiej w eseistyce polskiej lat 1945-1947: (Vincenz - Stempowski - Miłosz). Warszawa: Quantum, 1990. Print.

Kurowicki, Jan. Normalność jako sen idioty (wykłady o kulturowych i

filozoficznych kontekstach literatury współczesnej). Zielona Góra: Wydawnictwo Wyższej Szkoły Pedagogicznej im. T. Kotarbińskiego, 1994. Print.

Okopień, Krzysztof. "Dwie fenomenologie: Husserl i Gombrowicz". Wypowiedź literacka a wypowiedź filozoficzna. Z dziejów form artystycznych w literaturze polskiej. Eds. Michał Głowinski \& Janusz Sławiński. Wrocław: Wydawnictwo Polskiej Akademii Nauk, 1982. Print.

Markowski, Michał Paweł. "Czy możliwa jest poetyka eseju?" Poetyka bez granic. Z dziejów form artystycznych w literaturze polskiej. Eds. Włodzimierz Bolecki and Wojciech Tomasik. Warszawa: Instyłut Badań Literackich 1995. Print

Rosner, Katarzyna. "Ingardenowska koncepcja budowy dzieła literackiego jako źródło - inspiracji do analizy komunikacji artystycznej". Studia Semiotyczne 5 (1974). Print. Sławiński, Janusz. "Wypowiedź literacka a wypowiedź filozoficzna: trzy kwestie i jedna ponadto". Prace wybrane, vol. IV, Próby teoretycznoliterackie. Kraków: Universitas, 2000. Print.

---. "Wzmianka o eklektyzmie". Teksty i teksty. Kraków: Universitas, 2000. Print. 
Ulicka, Danuta. Ingardenowska filozofia literatury: konteksty. Warszawa: PWN, 1992. Print.

Wyka, Marta. "Próba parareli: Gustaw Herling-Grudziński i Albert Camus". Niecierpliwość kryłyki: recenzje i szkice z lat 1961-2005. Kraków: Universitas, 2006. Print.

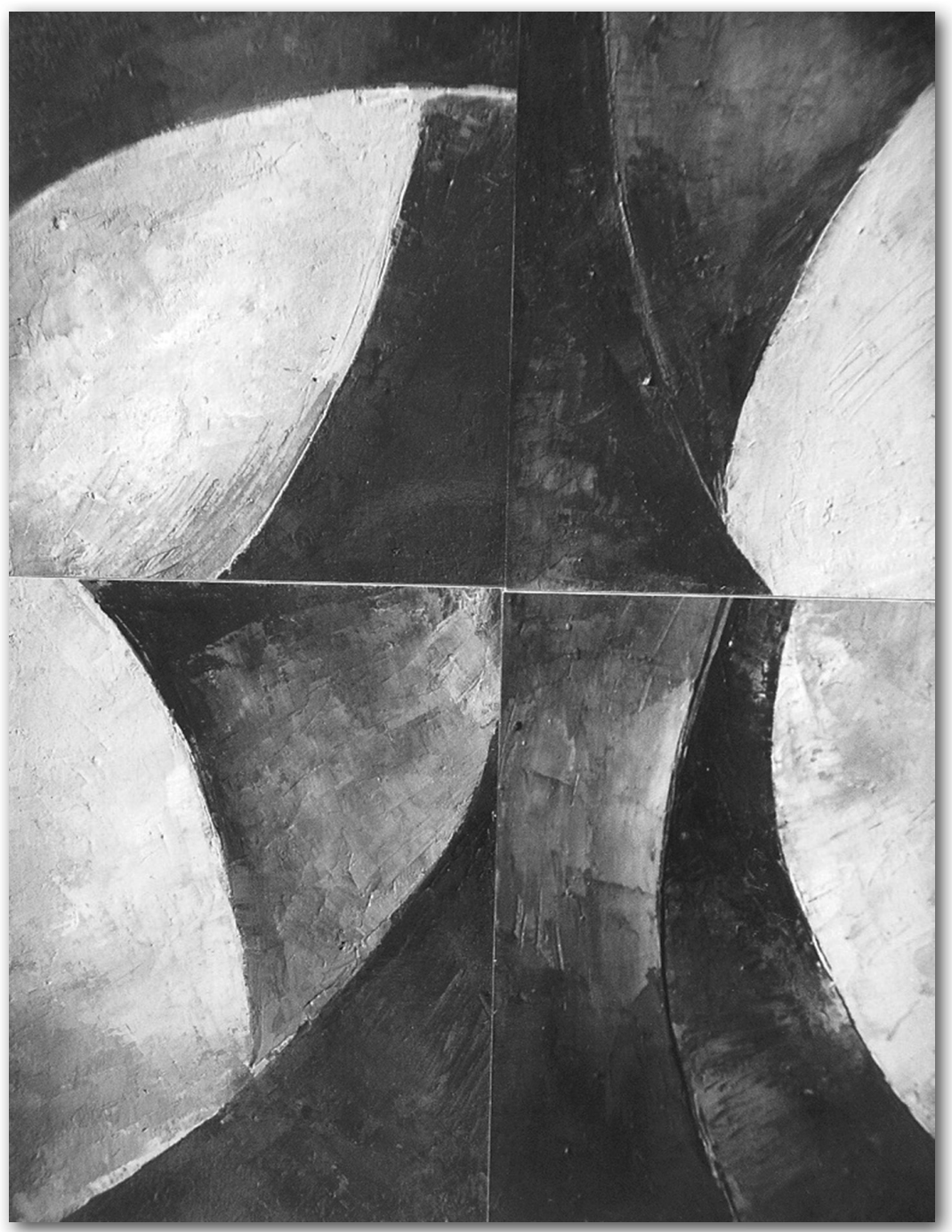

Roussanka Alexandrova-Nowakowska, Symmetry 2 